\title{
Postignuća u darivanju organa u Kliničkom bolničkom centru Rijeka
}

\section{Achievement in the organ donation in Clinical Hospital Centre Rijeka}

\author{
Željko Župan
}

Klinika za anesteziologiju, intenzivnu medicinu i liječenje bola, Klinički bolnički centar Rijeka, Rijeka

Dopisni autor:

Prof. dr. sc. Željko Župan, dr. med.

Klinika za anesteziologiju, intenzivnu medicinu i liječenje bola Klinički bolnički centar Rijeka Tome Strižića 3, 51000 Rijeka E-mail: zzupanri@gmail.com

\begin{abstract}
Sažetak. Hrvatska je jedna od vodećih zemalja svijeta po broju umrlih darivatelja organa i broju izvedenih transplantacija po glavi stanovnika godišnje. Klinički bolnički centar (KBC) Rijeka darivateljska je bolnica $s$ iznimno uspješnim programom darivanja organa te $s$ najboljim rezultatima u državi u tom području tijekom proteklog desetljeća. U KBC-u Rijeka ostvari se jedna četvrtina do petina svih solidnih organa namijenjenih transplantacijskom liječenju u Hrvatskoj s realiziranih 80 do 115 solidnih organa godišnje od 2012. do 2018. godine. U spomenutom razdoblju ostvario se i najveći apsolutni broj umrlih darivatelja te najveći broj solidnih organa za presađivanje u državi, unatoč činjenici da se darivateljski potencijal bolnice ne ubraja u najveće u Hrvatskoj. Porast broja darivatelja u KBC-u tijekom posljednjeg desetljeća simultano se odvijao s povećanjem broja darivatelja na nacionalnoj razini s naglaskom na činjenici da je regionalna stopa darivanja tijekom navedenog razdoblja u KBC-u Rijeka za 1,9 do 3,6 puta veća u odnosu na prosjek u državi. Stopa protivljenja darivanju organa od strane članova obitelji umrlih pacijenata iznosi samo $2,7 \%$ od 2011. do 2018. godine nakon obavljena 224 razgovora u tom razdoblju od strane članova tima bolničkih transplantacijskih koordinatora. Navedena stopa protivljenja iznimno je niska i značajno je niža u odnosu na nacionalni prosjek koji iznosi $20 \%$ i smatra se odličnim rezultatom u svijetu. KBC Rijeka se zahvaljujući navedenim dosezima u darivanju organa od umrlih snažno pozicionirao u vodeću darivateljsku bolnicu na nacionalnoj razini, visoko respektabilnu unutar međunarodne stručne zajednice u tom vrlo zahtjevnom području kliničke medicine bez koje razvoj kliničke transplantacije dokazano nije moguć.
\end{abstract}

Ključne riječi: darivanje organa; darivatelji organa; sustav dobave organa; transplantacija organa

Abstract. Croatia is one of the leading countries in the world due to the number of deceased organ donation and therefore in the number of transplants performed per capita annualy. The Clinical Hospital Center (CHC) Rijeka is a donor hospital with an exceptionally successful deceased donor program and with the best results in this field over the past decade in the country. At CHC Rijeka one-fourth to one-fifth of all solid organs intended for transplantation are realized in Croatia annualy and 80 to 115 solid organs per each year were performed from 2012 to 2018. In the mentioned period, the highest absolute number of deceased donors and the largest number of solid organs for transplantation in the country were realized in the UHC Rijeka despite the fact that the deceased donor potential of the hospital is not among the largest in Croatia. The number of donors in hospital over the last decade increased simultaneously with the rise in the number of donors at the national level with emphasis that the regional deceased donation rate during the mentioned period in $\mathrm{CHC}$ Rijeka is 1.9 to 3.6 times higher than the national average. The family refusal rate was only $2.7 \%$ from 2011 to 2018 after 224 interviews with family members which were conducted by the hospital transplant coordinators team members. The mentioned refusal rate at $\mathrm{CHC}$ Rijeka is extremely low and significantly lower than the national average rate which is $20 \%$ and as such is considered a very good result worldwide. Regarding to the above mentioned achievements in hospital organ deceased donation, CHC Rijeka is strongly positioned as a leading donor hospital at the national level and as highly respected institution within the international medical transplant community in this demanding field of a medicine without which the development of clinical transplantation is not possible.

Key words: organ donation; organ donors; organ procurement system; organ transplantation 


\section{UVOD}

Transplantacija solidnih organa danas je jedno od najzahtjevnijih multidisciplinarnih područja kliničke medicine i predstavlja najbolji način liječenja pacijenata sa završnim stadijem zatajivanja pojedinih organa. Broj raspoloživih organa za presađivanje nažalost ne prati stvarne potrebe iznimno razvijene transplantacijske medicine te nedostatak organa predstavlja globalni javnozdravstveni problem. U svijetu se recentno izvede oko 135000 transplantacija solidnih organa godišnje i unatoč tom impresivnom broju time se zadovolji samo oko $10 \%$ globalnih potreba ${ }^{1}$. Najmanje 10 - 30 \% pacijenata na listama čekanja za transplantacijsko liječenje godišnje umire ne dočekavši odgovarajući organ za presađivanje², stoga brojne zemlje i njihovi zdravstveni sustavi nastoje pronaći različite strategije i modele i pri tome ulažu ogromne napore i enormno visoka financijska sredstva s temeljnim ciljem povećanja broja darivatelja organa. Prema podacima Svjetske zdravstvene organizacije (WHO) smatra se da je primjeren nacionalni sustav darivanja organa ako ostvaruje $>20$ darivatelja na 1 milijun stanovnika (engl. per million population, pmp) tijekom jedne godine ${ }^{3}$. Nacionalni sustav darivanja organa u takvoj situaciji je dostatan i održiv u smislu opskrbe organa, budući da zadovoljava osnovne potrebe transplantacijske medicine jedne zemlje te opskrbljuje i novopridošle pacijente kojih je iz godine u godinu sve veći broj na rastućim listama čekanja.

Učinkovit sustav darivanja organa polazišni je uvjet razvoja transplantacijske medicine jedne zemlje te zadovoljavajuće uspješnosti ove prestižne kliničke discipline ${ }^{4}$. Uzimanje organa od umrlih, osobito od onih u kojih je smrt utvrđena neurološkim kriterijima, najveći je izvor organa za presađivanje (oko $80 \%$ ) te se napori za povećanje učinkovitosti darivateljskih sustava fokusiraju upravo na ovu skupinu mogućih darivatelja ${ }^{5}$.

Hrvatska je danas jedna od vodećih zemalja svijeta po broju ostvarenih, aktualnih, umrlih darivatelja organa i broju solidnih organa namijenjenih transplantaciji uzetih od umrlih s 34 - 42 darivatelja pmp na godišnjoj razini od 2011. do 2018. godine $^{6}$. Hrvatska je razvila međunarodno priznat, jedan od najuspješnijih modela darivanja organa od umrlih u svijetu te se sukladno velikom broju pribavljenih organa recentno izvede oko 80 do 100 transplantacija solidnih organa pmp godišnje, što je temeljem tih rezultata također svrstava među vodeće zemlje svijeta ${ }^{7,8}$.

Klinički bolnički centar (KBC) Rijeka najuspješniji je klinički centar te općenito darivateljska bolnica u Republici Hrvatskoj već dugi niz godina, po rezultatima ostvarenim u programu darivanja organa od umrlih osoba namijenjenih transplantacijskom liječenju ${ }^{9}$.

Hrvatska je jedna od najuspješnijih zemalja svijeta po broju ostvarenih solidnih organa namijenjenih presađivanju od umrlih darivatelja, stoga je po stopi izvedenih transplantacija godišnje među vodećim državama u svijetu. KBC Rijeka je darivateljska bolnica u državi s najboljim rezultatima u programu darivanja organa od umrlih tijekom proteklog desetljeća.

U KBC-u Rijeka se u posljednjih devet godina, od 2010. do 2018. godine, realizira prosječno četvrtina do petina svih solidnih organa raspoloživih za presađivanje u Hrvatskoj, kako u svakoj pojedinačnoj godini, tako i u sveukupnom apsolutnom zbroju $^{7-9}$. Danas KBC Rijeka, temeljem iznimnih rezultata koji se vrlo rijetko mogu naći i u literaturi u ovom vrlo zahtjevnom kliničkom području, može biti putokaz ostalim bolnicama u državi i regiji koje nastoje održivo povećati broj umrlih darivatelja organa ${ }^{10}$.

\section{POVIJESNI OSVRT I SADAŠNJE STANJE DARIVANJA ORGANA U HRVATSKOJ I KBC-U RIJEKA}

Tradicija darivanja organa od umrlih osoba u KBC-u Rijeka vrlo je duga i za razliku od drugih transplantacijskih centara u državi razvijala se usporedo s uvođenjem i unapređenjem transplantacije solidnih organa. Naime, već nakon prve, davne transplantacije bubrega u bivšoj državi, koja je učinjena u siječnju 1971. godine presatkom dobivenim od srodne žive osobe, već u svibnju 1972. godine izvedena je transplantacija bubrega organom uzetim od umrlog davatelja $u$ kojeg je smrt potvrđena cirkulacijskim kriteriji$m a^{11}$. KBC Rijeka, tada dio bolničkih kapaciteta na 
lokalitetu Sušak, nije poznat samo po činjenici da je u njemu učinjena prva uspješna transplantacija bubrega u bivšoj državi i regiji, već i po prvom uzimanju organa od umrle osobe za presađivanje na ovim područjima. Evidentno je kako je razvoj sveukupnog bolničkog sustava koji je omogućio prvu transplantaciju bubrega, a koji je uključivao unapređenje kirurških tehnika, uvođenja imunogenetskog testiranja pacijenata i imunosupresivnih lijekova, razvoja nefrologije i dijaliznih tehnika bio istodobno praćen i brigom o uspostavljanju uspješnog modela darivanja organa. Već tada je postojala vizija i svijest o potrebi i značenju uspostavljanja dugoročne strategije i uspješnog modela bolničkog i nacionalnog sustava darivanja organa od umrlih osoba kao temeljnom preduvjetu kasnijeg razvoja transplantacijske medicine. Navedeno razumijevanje razvoja darivanja organa od umrlih osoba bilo je „korak ispred vremena" i vrlo vizionarski pristup u to vrijeme. Valja napomenuti kako je uzimanje organa od umrlog davatelja 1972. godine učinjeno 10 godina nakon prve transplantacije bubrega presatkom uzetim od umrle osobe izvedene u Bostonu, USA, te samo četiri godine nakon što su objavljeni Harvardski kriteriji koji predstavljaju ključni stručni dokument na svjetskoj razini za utvrđivanje dijagnoze smrti pacijenata primjenom neuroloških kriterija kojima su postavljeni preduvjeti za darivanje organa od strane umrlih osoba s očuvanom cirkulacijom $^{12}$.

Unatoč rano izvedene transplantacije model darivanja organa na nacionalnoj razini bio je slabo razvijen dugi niz godina nakon toga i Hrvatska se po broju ostvarenih darivatelja organa, u to vrijeme, nalazila na samom začelju Europe.

Suprotno tome, u KBC-u Rijeka darivanje organa bilo je poprilično razvijeno s relativno zadovoljavajućim brojem organa uzetih od živih i umrlih osoba. U svojim počecima izvor organa za presađivanje većim djelom bili su živi srodni darivatelji, što se devedesetih godina prošlog stoljeća mijenja kada se za transplantacije bubrega uglavnom koriste organi od umrlih osoba. Od 1971. godine do 1996. godine u KBC-u Rijeka izvršeno je 615 transplantacija bubrega i od tog broja u 318 pacijenata ili $52 \%$ organ je dobiven od živog darivatelja, a u 297 pacijenata ili $48 \%$ bubreg za presađivanje uzet je od umrlog davatelja ${ }^{13}$. Evidentno je kako je u navedenom razdoblju godišnje ostvarivano prosječno oko 10 do 12 transplantacija bubrega s organima od umrlih darivatelja. $U$ to vrijeme to je predstavljalo veliku razliku u odnosu na druge bolnice u bliskom i daljem okruženju koje su imale transplantacijski program. Transplantacija bubrega se $u$ to vrijeme obavljala u centru gdje je ostvaren umrli darivatelj organa tako da je odabrani primatelj s bolničke ili jedinstvene republičke liste čekanja, koja je uspostavljena između 1985. i 1990. godine, dolazio u bolnicu davatelja organa. U to vrijeme lakše, a i stručno opravdanije, bilo je da primatelj dolazi na mjesto uzimanja organa nego da se organ u tada neoptimalnim uvjetima i neprimjereno protektiran transportira do bolnice gdje se vrši presađivanje. Takvim sustavom favorizirane su i darivateljske bolnice, budući da je davatelja organa tada bilo vrlo malo i organi za presađivanje predstavljali su dragocjen ulog. To je bilo moguće provesti također i stoga što se transplantacija bubrega obavljala u samo dva centra u Republici, u Zagrebu i Rijeci. S obzirom na niz logističkih i organizacijskih problema s ciljem poboljšanja suradnje i unaprjeđenja izmjene organa kasnih osamdesetih godina, inicijativom iz Rijeke, uočava se potreba za osnivanjem krovne organizacije transplantacijske medicine i darivanja organa, Crotransplant. Nažalost, tadašnje društveno-povijesne i političke okolnosti nisu išle u prilog takvom razvoju događaja, te nakon raspada Jugoslavije i osamostaljenja Republike Hrvatske nacionalna zdravstvena politika ima druge prioritete $s$ gotovo potpunim prekidom trasplantacijskih aktivnosti na nacionalnoj razini. Unatoč tome, presađivanje i darivateljstvo organa se u Rijeci održavalo i u vrijeme Domovinskog rata, s posebnom pažnjom usmjerenom prema osiguranju temeljnih etičkih principa i s posebnim pijetetom prema žrtvama rata, tako da se one nisu koristile kao mogući darivatelji organa. Više godina nakon stjecanja nezavisnosti Republike Hrvatske, od 2000. godine nadalje, broj transplantacija bubrega u KBC-u Rijeka stabilizirao se prosječno na oko 20 do 25 transplantacija bubrega godišnje s organima dobivenim većinom od umrlih osoba. Istovremeno se u Rijeci ostvarivalo prosječno oko 8 do 10 multiorgankih umrlih dari- 
vatelja organa na godišnjoj razini. Na razini Hrvatske navedeni broj darivatelja organa iz KBC-a Rijeka predstavljao je respektabilan broj s obzirom na mali broj davatelja organa na razini cijele države (od 2,7 - 13,3 darivatelja pmp godišnje od 2002. do 2007. godine; ukupno 12 do 60 darivatelja godišnje ${ }^{14}$. Brojni nekompatibilni bubrezi i ostali organi dobiveni od umrlih darivatelja iz Rijeka odlazili su u druge centre u državi i šire. Lista čekanja na presađivanje bubrega u KBC-u Rijeka se nakon administrativno-organizacijskih promjena početkom prošlog desetljeća ograničila na 30 do 40 pacijenata u aktivnom statusu za transplantacijsko liječenje, što se zadržalo do današnjih dana. Transplantacijska je aktivnost u KBC-u Rijeka do 2006. godine i prvog uspješnog presađivanja jetre isključivo bila vezana za transplantaciju bubrega. 1995. godine učinjeno je više kombiniranih transplantacija bubrega i gušterače, ali je svih pet transplantiranih pacijenata umrlo ubrzo nakon presađivanja, u najvećem broju neposredno nakon operacije.

Izuzetno mali broj darivatelja organa i izvedenih transplantacija na nacionalnoj razini nakon završetka rata alarmirao je širu stručnu i sveukupnu javnost te je potaknuo Hrvatski državni sabor na donošenje Rezolucije o poticanju presađivanja organa (NN 32/1999.). Naputkom za Provođenje programa o eksplantaciji organa (NN 75/1998.) od strane Ministarstva zdravstva (MZ) u sve akutne bolnice uvedena je mreža bolničkih transplantacijskih koordinatora (BTK) na nacionalnoj i bolničkoj razini po poznatom „španjolskom modelu“. U sve akutne bolnice u državi (u 50-ak bolnica) u potencijalne darivateljske bolnice uvedeni su BTK, mahom intenzivisti, te su utvrđeni ciljevi, mjere i način provedbe Programa za povećanje broja eksplantacije organa u Republici Hrvatskoj. U tom razdoblju uspostavlja se niz novih organizacijskih mjera za unaprjeđenje darivanja organa, formira se Nacionalno transplantacijsko tijelo, uvodi se Nacionalni transplantacijski koordinator, liječnik stalno zaposlen u punom radnom vremenu pri Ministarstvu zdravlja, uspostavljeno je 24 satno dežurstvo za koordinaciju svih aktivnosti vezanih za uzimanje i presađivanje organa, dorađeni su zakonski okviri te uvedene dodatne financijske potpore bolnicama povezane s darivanjem organa i transplantacijskom medicinom. Valja naglasiti kako sličnu organizaciju i političku podršku darivanju organa ima niz zemalja u regiji i značajno šire te ne ostvaruju ni približno rezultate kao Hrvatska. Evidentno su kompetencije profesionalaca i kapacitet kliničkih lidera koji su uključeni u sustav od presudnog značenja za njegov uspjeh. Na razinama nacionalnih stručnih društava, osobito anesteziologa i intenzivista, neurologa i šire, provodi se intenzivna stručna kampanja u svezi dokazanih metoda za unapređenja sustava darivanja organa i povećanje broja darivatelja. Skup novih zakonskih, financijskih, a prije svega organizacijskih i stručnih mjera u konačnici rezultira stalnim porastom broja darivatelja organa na nacionalnoj razini od 2000. godine nadalje te darivateljskim boomom u 2010. godini, kada broj realiziranih darivatelja raste za $64 \%$ u odnosu na prethodnu godinu, na vrlo visokih 28,66 ostvarenih aktivnih darivatelja pmp godišnje. Tim rezultatom Hrvatska se pozicionirala na prvo mjesto unutar Eurotransplanta i svrstala uz bok Španjolskoj, Belgiji, Portugalu, državama s najvećim brojem ostvarenih umrlih darivatelja organa u svijetu s iznimno visokom stopom izvedenih transplantacija (slika 1).

Nakon tog booma Hrvatska ne samo da je zadržala tako visoku razinu darivanja organa, već je čak i poboljšala stopu ostvarenih darivatelja, te je ona nadalje iznosila > 30 pmp i podigla se na 41,5 realiziranog darivatelja u 2018. godini, razinu koju je do sada u svijetu ostvarila još jedino Španjolska. Hrvatska predstavlja jednu od rijetkih zemalja svijeta koja je u dvanaestgodišnjem razdoblju povećala broj umrlih darivatelja od 2006. do 2018. za više od tri puta te je podigla na najviše razine $u$ svijetu > 40 darivatelja pmp godišnje (slika 2). Hrvatska je također najučinkovitija zemlja unutar Eurotransplanta po broju ostvarenih umrlih darivatelja. Od 2010. godine pa sve do današnjih dana, već dvije godine nakon punopravnog članstva unutar te ugledne neprofitne međunarodne organizacije, Hrvatska ostvaruje daleko najveći broj umrlih darivatelja organa na godišnjoj razini. Nijedna članica od ostalih sedam zemalja Eurotransplanta nije zabilježila tako velik, eksponencijalni porast darivatelja unutar te organizacije koja obuhvaća osam država u Europi i 135 milijuna lju- 


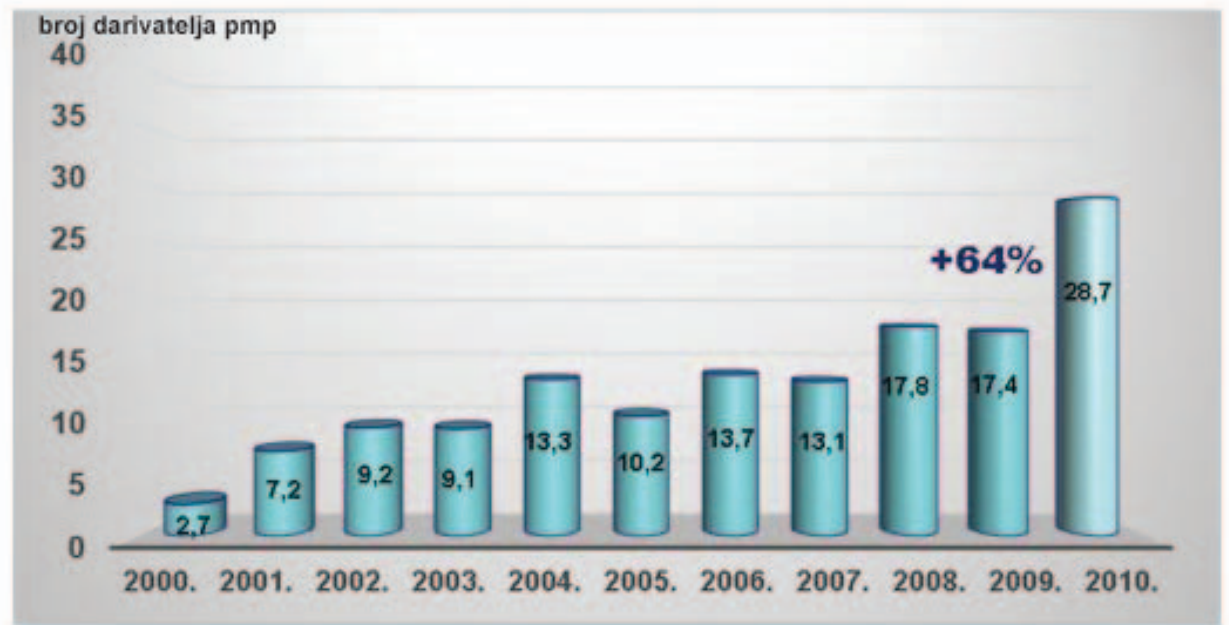

Slika 1. Prikaz porasta broja umrlih darivatelja organa u Hrvatskoj u vremenskom razdoblju od 2000. do 2010. godine. (pmp - broj darivatelja na 1 milijun stanovnika godišnje)

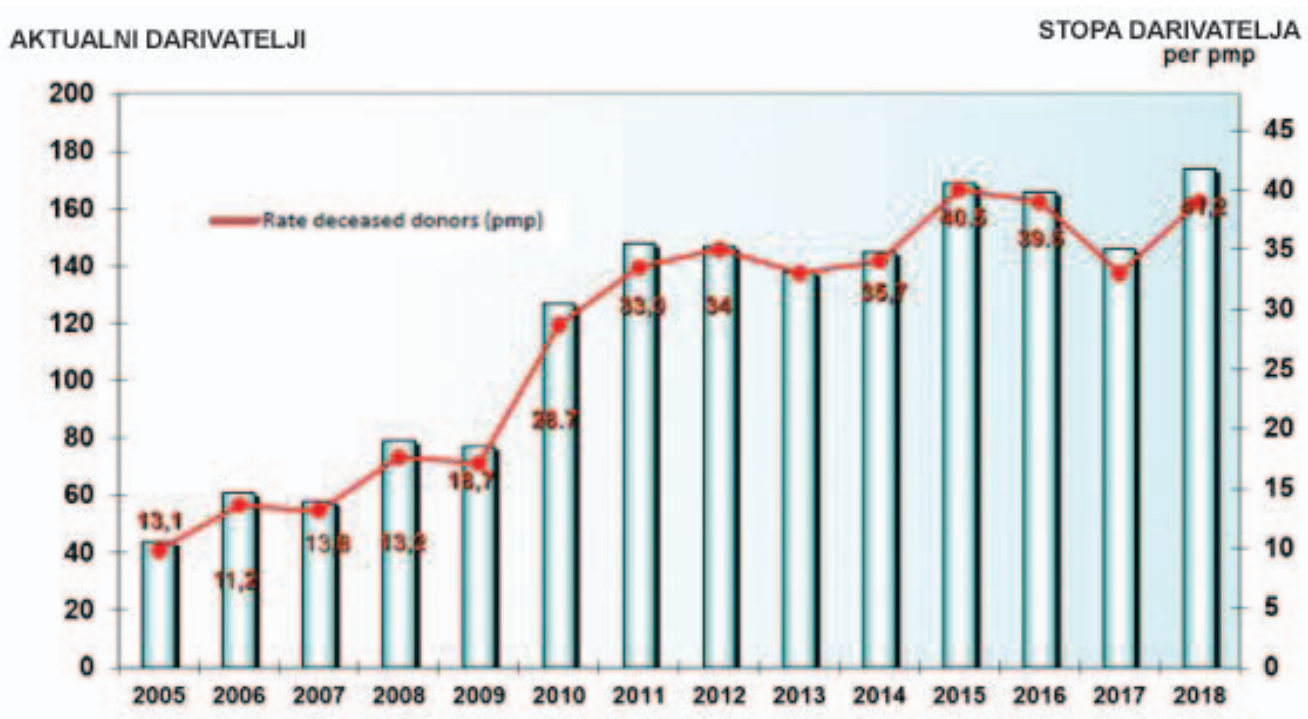

Slika 2. Prikaz porasta broja darivatelja organa u Hrvatskoj u vremenskom razdoblju od 2005. do 2018. godine.

di, a namijenjena je optimalnoj alokaciji organa za transplantaciju te prekograničnoj izmjeni organa za presađivanje od preminulih osoba (slika 3). Od ulaska Hrvatske u Eurotransplant u svibnju 2007. godine alokacija organa vrši se unutar te organizacije gdje se prikupljaju svi relevantni podaci o svim darivateljima iz Hrvatske te se vrši odabir primatelja sa zajedničke nacionalne liste, koji su razvrstani unutar transplantacijskih centara u državi. U KBC-u Rijeka se od 2006. godine nakon personalnih $\mathrm{i}$ organizacijskih promjena $\mathrm{u}$ bolničkom BTK sustavu bilježi stalan porast broja umrlih da- rivatelja organa. Broj ostvarenih umrlih darivatelja organa i broj solidnih organa namijenjenih presađivanju počinje eksponencijalno rasti, pa u 2013., 2014. i 2015. godini dosiže najvišu razinu > 30 realiziranih umrlih darivatelja organa godišnje. Od 2007. godine pa do današnjih dana bolnički sustav darivanja organa bilježi stalan porast umrlih darivatelja organa, najprije na bolničkoj, a potom od 2010. i na nacionalnoj razini. U KBC-u Rijeka se sada već skoro cijelo desetljeće ostvaruje najveći broj umrlih darivatelja organa u državi, unatoč činjenici da KBC Rijeka, grad Rijeka i Primorsko-go- 


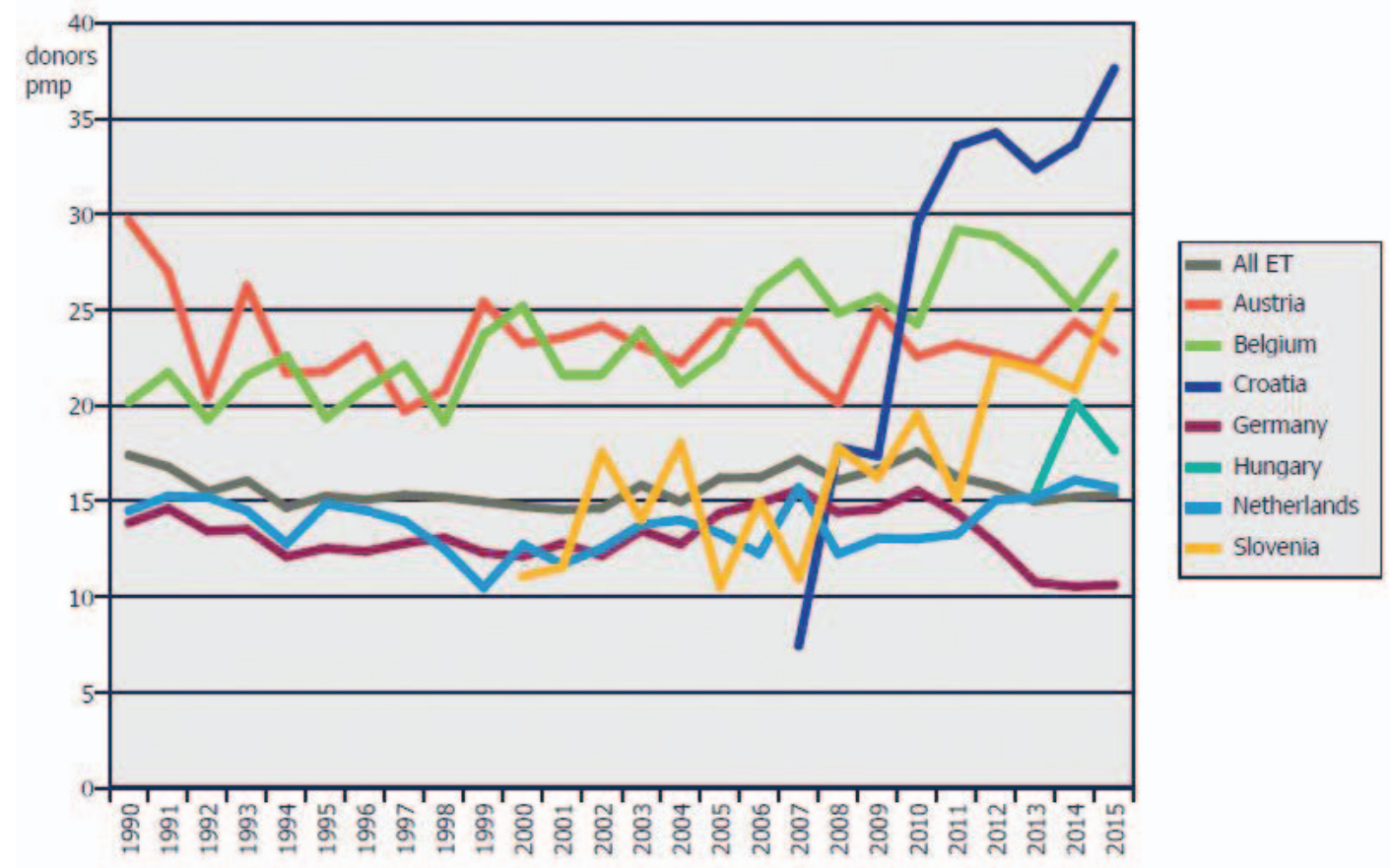

Slika 3. Prikaz porasta broja ostvarenih umrlih darivatelja organa u Hrvatskoj u odnosu na druge članice Eurotransplanta, preuzeto iz Eurotransplant Annual Report 2015.

ranska županija nemaju najveći darivateljski potencijal u odnosu na niz drugih bolnica i regija $u$ državi. Darivateljski potencijali bolnica i mogućnost darivateljstva od strane pacijenata nakon smrti mozga također korelira sa sveukupnim brojem umrlih u njima i iznosi oko 1 \% od sveukupnog broja umrlih u bolnici na godišnjoj razini te ne više od $3 \%$ umrlih, s napomenom kako je od toga broja oko $20 \%$ medicinski neprihvatljivo za darivanje organa. Dvanaest do $14 \%$ od svih umrlih u jedinicama intenzivne medicine (JIM) mogući su darivatelji organa na godišnjoj razini ili $8 \%$ umrlih u JIM u bolnicama koje nemaju neurokirurške odjele. Od tog broja oko $20 \%$ umrlih pacijenata nije prihvatljivo za darivanje organa namijenjenih transplantacijskom liječenju ${ }^{15}$. Iz iznesenih podataka lako je zaključiti kako je darivateljski potencijal KBC-a Rijeka niži gotovo od svih kliničkih centara te nekih kliničkih bolnica u državi.

Navedenim rezultatima KBC Rijeka se u posljednjem desetljeću prometnuo u vodeći i međunarodno priznat centar za darivanje solidnih organa namijenjenih presađivanju s vrlo respektabilnim rezultatima na nacionalnoj i internacionalnoj razini ${ }^{16,17}$.

\section{OSOBITOSTI PRIKUPLJANJA ORGANA OD UMRLIH U KBC-U RIJEKA}

\section{Rezultati sustava darivanja organa od umrlih osoba}

U KBC-u Rijeka bilježi se stalan porast broja ostvarenih umrlih darivatelja organa od 2007. godine nadalje. Od 2007. do 2012. godine broj darivatelja rastao je kako slijedi: 8, 13, 16, 21, 19 te 26 realiziranih umrlih darivatelja organa na godišnjoj razini. Dodatno značajno povećanje na 33 ostvarena multiorganska umrla darivatelja bilježi se u 2013. te u 2014. godini, dok je u 2015. godini realiziran 31 davatelj organa. U 2016., 2017. i 2018. godini ostvaren je nešto manji broj, s 27, 21 te 26 darivatelja godišnje, ali još uvijek na iznimno visokoj razini (> 20 darivatelja godišnje), što također predstavlja najveći broj darivatelja po darivateljskim bolnicama u Hrvatskoj. U svim navedenim godinama KBC Rijeka je bolnica s evidentno najvećim brojem umrlih darivatelja organa u Hrvatskoj. Od 2007. do 2013. godine uobičajeni broj darivatelja koji se ostvarivao prije toga uvećan je za 4 puta ili za $300 \%$ na iznimno 


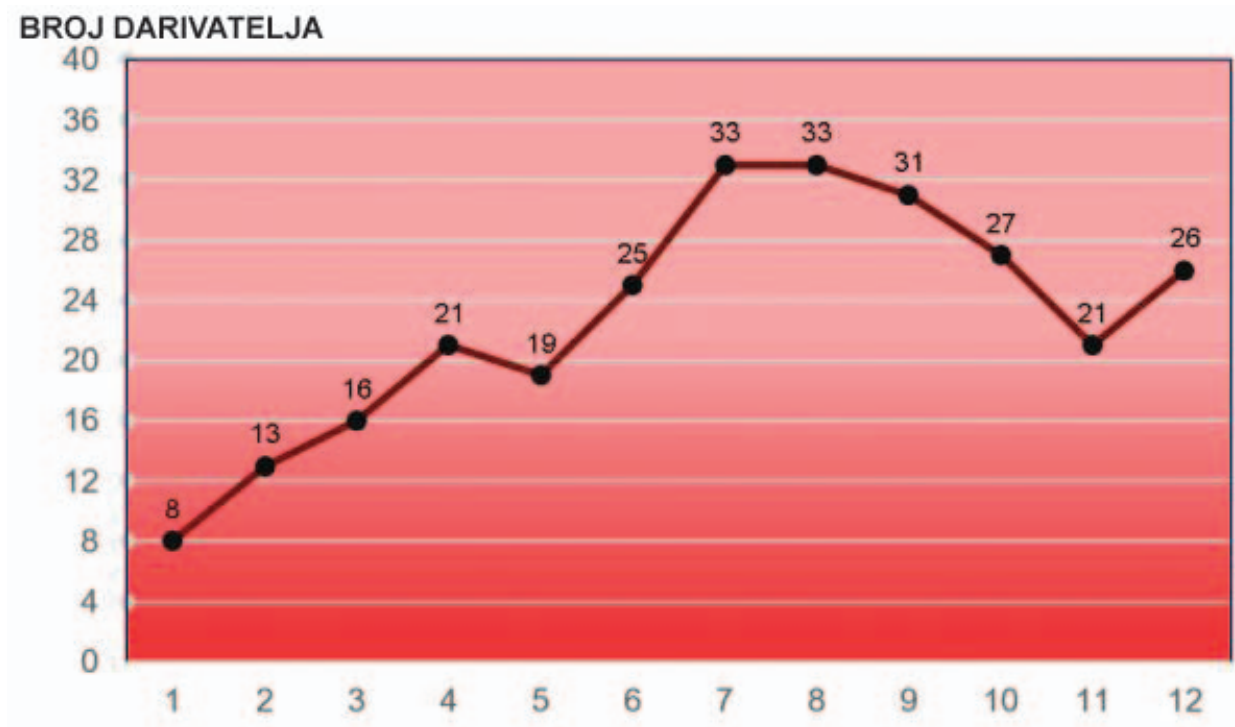

Slika 4. Prikaz porasta broja umrlih darivatelja organa ostvarenih u KBC-u Rijeka u vremenskom razdoblju od 2007. do 2018. godine.

visoku bolničku razinu te se na tom visokom nivou uglavnom zadržao sve do danas (slika 4). Razloge za navedeno povećanje broja ostvarenih darivatelja u bolnici koja je i prethodno bilježila prihvatljiv broj darivatelja organa treba tražiti u nizu stručnih i organizacijskih promjena koje se kao i u drugim uspješnim bolnicama u svijetu u tom segmentu, dokazano, prvenstveno odnose na pristup i kvalitetu liječenja pacijenata s visokim rizikom za razvoj smrti mozga i primjereno održavanje potencijalnih darivatelja ${ }^{18,19}$. Temeljne promjene vezane su za djelatnost intenzivne medicine te rad BTK tima. Naime, u Hrvatskoj je već više od 20 godina prikupljanje organa od umrlih isključivo bazirano na darivateljstvu nakon smrti mozga, budući da uzimanje organa nakon cirkulacijske smrti osobe nije dozvoljeno zakonom. Ne postoje dokazi u medicini koji bi govorili u prilog činjenici kako je nedostatak navedenih darivatelja posljedica njihova pomanjkanja u bolnici, već naprotiv, značajno češće njihov nedostatak povezan je $s$ njihovim neprepoznavanjem, neadekvatnim intenzivnim liječenjem i općenito neprimjerenim pristupom pacijentima s teškim oštećenjem mozga, s neadekvatnim održavanjem mogućih darivatelja organa, s velikim stupnjem protivljenja darivanju organa te s problemima vezanim za realizaciju uzimanja organa ${ }^{20}$. Evidentno je kako je sve to u KBC-u Rijeka adekvatno prevladano te je za ovako velik broj ostvarenih umrlih darivatelja zaslužan kompetentan i motiviran bolnički tim BTK-a, dobra organizacija te pozitivan proaktivan pristup cijele bolnice. KBC Rijeka na taj način postaje bolnica u državi s najvećim brojem ostvarenih darivatelja i s najvećim brojem uzetih organa za presađivanje u posljednjem desetljeću.

Od 2012. do 2014. godine u Hrvatskoj je realiziran 431 darivatelj organa, a od tog broja u KBC-u Rijeka ostvarena su 92 darivatelja ili $22 \%$ od ukupnog broja darivatelja organa u državi, dok istovremeno udio u ukupnom broju ostvarenih solidnih organa namijenjenih transplantaciji na nacionalnoj razini iznosi od $25-30 \%$.

Razmatrajući pojedinačni broj ostvarenih solidnih organa raspoloživih za presađivanje i izvedenih transplantacija u spomenutom vremenskom razdoblju u KBC-u Rijeka ostvaruje se prosječno 90 do 100 solidnih organa namijenjenih presađivanju na godišnjoj razini. $U$ vremenskom razdoblju od 2011. do 2015. godine realizirane su 134 jetre, 257 bubrega, 40 pluća, 38 srca, 11 gušterača te oko 150 očnih bulbusa namijenjenih transplantacijskom liječenju. Evidentno je kako je u navedenom petogodišnjem razdoblju ostvareno i transplantirano 480 solidnih organa, 96 organa prosječno godišnje u KBC-u Rijeka ${ }^{7-9}$. 
U KBC-u Rijeka također se ostvari najveći broj pluća i srca za presađivanje na razini države, pa u posljednjem desetljeću gotovo $50 \%$ od sveukupnog broja pluća i srca za transplantacijsko liječenje u Republici Hrvatskoj dolazi iz Rijeke. Optimalna stopa darivanja pluća iznosi oko $30 \%$ u svijetu, nešto manje za srce, u odnosu na ukupan broj svih drugih organa namijenjenih transplantaciji na godišnjoj razini. Navedena stopa ostvarena u KBC-u Rijeka jedna je od najviših u Eurotransplantu.

U spomenutom razdoblju prosječno je ostvareno i transplantirano 3,8 \pm 4,2 solidna organa po darivatelju, što predstavlja iznimno visok broj transplantiranih organa po jednom darivatelju, $u$ usporedbi s drugim bolnicama u Hrvatskoj i podacima iz literature. Naime, prosjek uzetih organa po darivatelju iznosi oko 2,5 u Hrvatskoj i nizu ostalih zemalja svijeta, pa čak i kod značajno mlađih darivatelja organa ${ }^{21}$. Dokazano je kako visok prosječan broj transplantiranih organa po darivatelju, uz uvjet da se darivatelji organa ne razlikuju značajno u prosječnoj životnoj dobi, direktno korelira s visokom kvalitetom intenzivne medicine tijekom skrbi o pacijentu te kasnije s održavanjem darivatelja organa. Općenito, kvaliteta skrbi koja je pružena pacijentima i kasnije darivateljima organa dokazano utječe na broj darivatelja, broj i kvalitetu organa za transplantacijsko liječenje po darivatelju te preživljavanje primatelja ${ }^{22}$.

Ostvareni umrli darivatelji u KBC-u Rijeka u posljednjem desetljeću nisu mlađe životne dobi, već naprotiv, njihova prosječna dob iznosi 56,3 godine. Spomenuta dob umrlih darivatelja odgovara recentnoj srednjoj dobi darivatelja u Hrvatskoj i drugim uspješnim državama s respektabilnim brojem darivatelja, poput Španjolske, Belgije i Portugala. Transplantacijska medicina se danas evidentno suočava s činjenicom da organi za presađivanje dolaze od sve starije i bolesnije populacije, stoga je povezana s povišenim rizikom razvoja komplikacija tijekom i nakon transplantacije.

Primjereno liječeni pacijenti s teškim oštećenjima mozga od prijema u bolnicu imaju veću šansu preživljavanja, ali se, isto tako, takvim pristupom osigurava i veći broj viabilnih organa raspoloživih za potencijalno presađivanje u slučaju razvoja smrti mozga. U umrlih darivatelja starijih od 50 godina rizik oštećenja somatskih organa dodatno je naglašen, budući da je njihova fiziološka rezerva smanjena ${ }^{23}$.

Najmlađi ostvaren darivatelj organa u KBC-u Rijeka bila je umrla beba stara 17 dana, inače također najmlađi realizirani darivatelj organa na razini Hrvatske, a najstarija je bila umrla darivateljica u dobi od 86 godina. Evidentno je kako je dobna granica za darivatelje organa vrlo upitna, a danas se sve više smatra kako postoje samo marginalni primaoci organa.

U KBC-u Rijeka ostvari se jedna četvrtina do petina svih solidnih organa namijenjenih transplantacijskom liječenju u Hrvatskoj na godišnjoj razini u posljednjih deset godina. Regionalna stopa ostvarenih umrlih darivatelja organa u KBC-u Rijeka je 1,9 do 3,6 puta veća od nacionalnog prosjeka. Stopa protivljenja darivanju organa iznimno je niska u KBC-u Rijeka (2,7\%), a u posljednje tri godine nije zabilježeno niti jedno protivljenje obitelji umrlih darivanju organa.

KBC Rijeka jedina je zdravstvena ustanova u Hrvatskoj koji je na nacionalnoj razini prema broju ostvarenih darivatelja organa, temeljem objektivne metode procjene darivateljskog potencijala od strane MZ-a svrstana u kategoriju „iznad očekivanog" po broju darivatelja u 2013. i 2014. godini. Sukladno tome voditelju BTK tima je i 2016. godine $\mathrm{MZ}$ uručio osobno priznanje za ostvarene iznimne dosege.

Bolnice sa zadovoljavajućim brojem ostvarenih darivatelja organa u Hrvatskoj u vremenskom razdoblju od 2012. do 2014. godine su još KBC Sestre milosrdnice iz Zagreba s 24, 15 i 18 darivatelja te Opća bolnica Varaždin s 18, 20 i 25 darivatelja organa na godišnjoj razini. Danas se po broju ostvarenih darivatelja organa uz bok KBC-u Rijeka nalaze KBC Osijek, KBC Sestre milosrdnice, te Opća bolnica Varaždin i Klinička bolnica Dubrava (slika 5).

\section{Stopa protivljenja darivanju organa}

Darivateljski sustav KBC-a Rijeka također se ističe po postignutoj vrlo niskoj stopi protivljenja darivanju organa od strane članova obitelji umrlih. Naime, stopa protivljenja iznosi svega 2,7\% u 


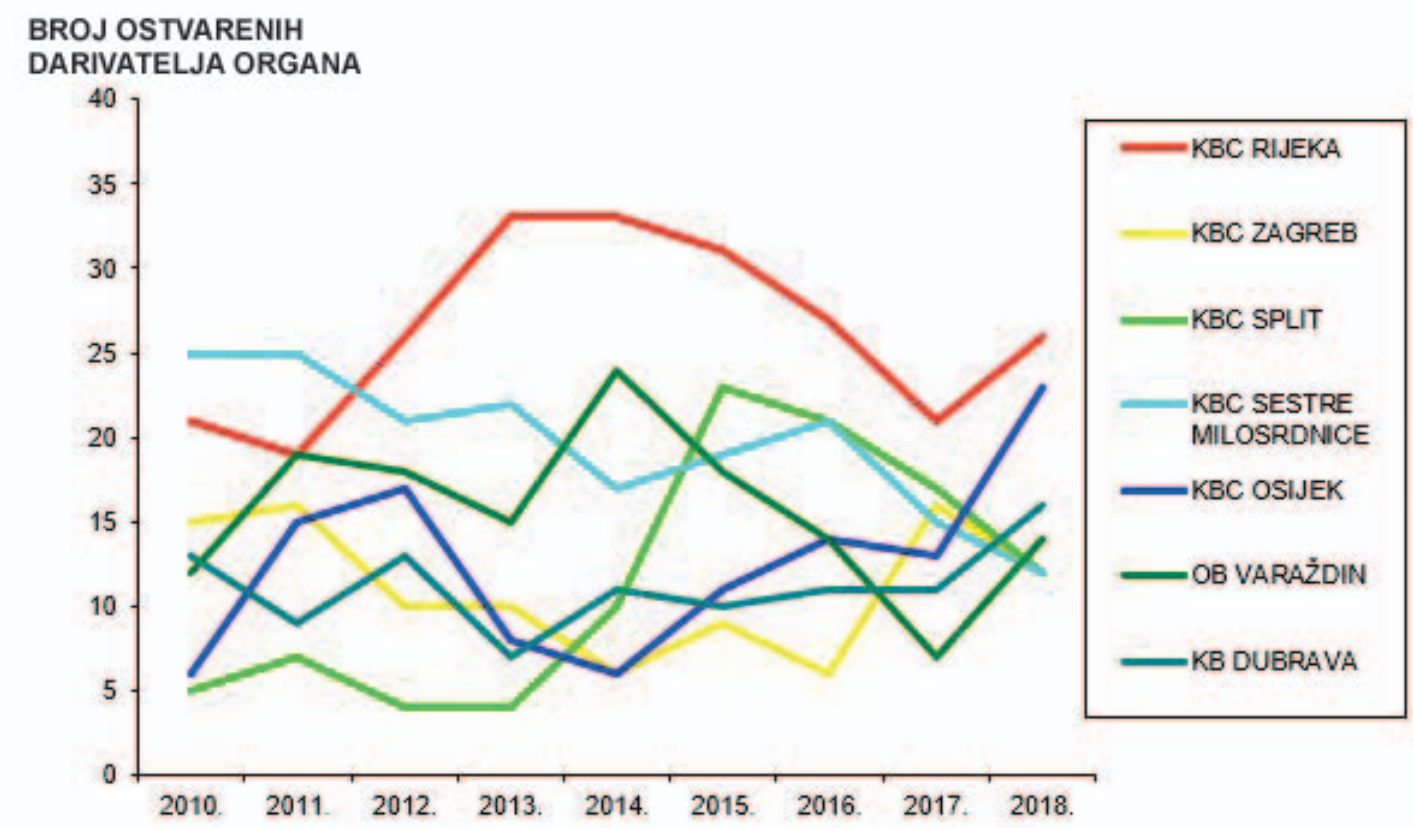

Slika 5. Prikaz broja ostvarenih umrlih darivatelja organa po darivateljskim bolnicama u Hrvatskoj u vremenskom razdoblju od 2010. do 2018. godine prema podacima Ministarstva zdravstva Republike Hrvatske iz prosinca 2019. godine.

vremenskom razdoblju od 2011. do 2018. godine i jedna je od najnižih u odnosu na ostale bolnice u Hrvatskoj i regiji, pa i značajno šire (slika 6). U

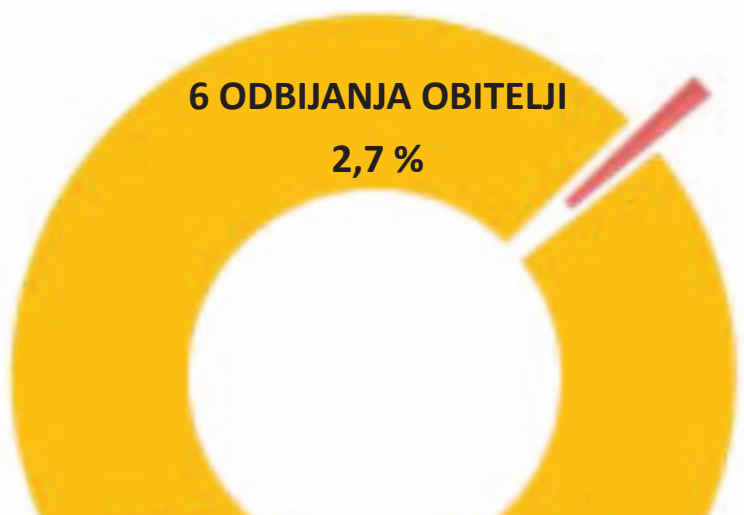

224 POTENCIJALNIH DARIVATELJA

97,2 \% PRISTANAK

\section{DARIVATELJA}

Slika 6. Prikaz stope protivljenja darivanju organa od strane članova obitelji umrlih pacijenata u KBC-u Rijeka u vremenskom razdoblju od 2011. do 2018. godine. posljednje tri godine nije zabilježeno ni jedno protivljenje darivanju organa od strane članova obitelji, što je izniman rezultat. Ovako visoka stopa neprotivljenja rezultat je visoke razine solidarnosti i svijesti o značenju darivanja organa naših ljudi te pažnji, umješnosti i empatiji članova BTK tima koji isključivo obavljaju razgovore o darivanju organa s članovima obitelji.

Stopa protivljenja obitelji u Republici Hrvatskoj recentno prosječno iznosi oko $20 \%$ za 2018. godinu, dok u Europi značajno varira i kreće se u rasponu od 30 do $50 \%$. Stupanj odbijanja obitelji umrlog na nacionalnoj razini odgovara iskustvima u Španjolskoj, zemlji s najuspješnijim sustavom darivanja organa u svijetu i smatra se odličnim rezultatom u Europi. O ovako niskoj stopi odbijanja na obavljenom velikom broju razgovora koja je zabilježena u KBC-u Rijeka i k tome kroz tako dugo vremensko razdoblje iznimno je rijetka i praktički nema podataka u literaturi o sličnim rezultatima $^{24}$.

Nije zamijećeno kako se pripadnici pojedinih etničkih, religioznih ili drugih skupina posebno protive darivanju organa u KBC-u Rijeka, što se vrlo često ističe kao razlog neučinkovitosti darivatelj- 
skih sustava u drugim regijama u Hrvatskoj te u matičnim državama nekih etničkih skupina.

\section{Regionalna stopa darivanja organa}

Regionalna stopa ostvarenih umrlih darivatelja organa na godišnjoj razini proračunava se tako da se broj aktualnih darivatelja projicira na odnos stvarnog broja stanovnika regije o kojoj skrbi darivateljska bolnica prema 1 milijunu stanovnika, pmp. U Rijeci se taj broj, primjerice, proračunava tako da se broj ostvarenih darivatelja organa na godišnjoj razini umnaža s odnosom 1 milijuna stanovnika $i$ broja žitelja Primorsko-goranske županije, u Puli prema odnosu 1 milijuna i broja stanovnika Istarske županije, a u Zagrebu prema zbroju svih ostvarenih darivatelja godišnje u zagrebačkim darivateljskim bolnicama u odnosu na 1 milijun stanovnika i broja žitelja Zagrebačke županije. Jedan je od vrlo objektivnih pokazatelja uspješnosti darivateljskih programa u pojedinim bolnicama ili čak regijama u kojima ima više darivateljskih centara. Sukladno regionalnoj stopi ostvarenih darivatelja KBC Rijeka dosegao je najviše svjetske standarde u darivanju organa, a neke od njih postavio čak i na jedinstvenu, vrlo visoku razinu (slika 7).

U Primorsko-goranskoj županiji ili u KBC-u Rijeka je u 2013. i 2014. godini iz regionalne stope darivanja vidljivo kako je ostvareno 3,6 puta više darivatelja organa po glavi stanovnika u odnosu na nacionalni prosjek, po kojem se Hrvatska svrstava među vodeće zemlje svijeta. U posljednjem desetljeću spomenuta regionalna stopa kreće se u rasponu od 64 do 110 darivatelja pmp godišnje i 1,9 do 3,6 puta je veća od nacionalnog prosjeka, ovisno o vremenskom razdoblju u kojem se prati. Ovako visoka regionalna stopa potvrđuje recentna saznanja kako stopa ostvarenih darivatelja organa može iznositi i značajno više od 50 darivatelja pmp godišnje, što se ne tako davno smatralo gornjom granicom ${ }^{25}$. Tako visoka regionalna stopa ostvarenih darivatelja organa na godišnjoj razini > 100 darivatelja pmp godišnje do sada nije zabilježena u relevantnoj literaturi, a približava joj se jedino regionalna stopa darivanja od 74,2 ostvarena darivatelja pmp navedena $u$ sjevernoj Španjolskoj pokrajini u 2007. ${ }^{15}$ Španjolska Nacionalna organizacija za transplantacijsku medicinu u izvještaju za 2018. godinu navodi kako je u toj najuspješnijoj zemlji svijeta po rezultatima programa darivanja organa, autonomna regija Cantabria postigla najvišu regionalnu stopu darivanja od 86,2 darivatelja pmp na nacionalnoj razini ${ }^{26}$. Približno iznimno visoku regionalnu stopu darivanja organa u Hrvatskoj > 100 darivatelja pmp godišnje ostvarila je i Opća bolnica Varaždin u razdoblju od 2012. do 2013. godine, ali s puno nižim prosječnim brojem transplantiranih organa po darivatelju u odnosu na prosjek KBC-a Rijeka ${ }^{8}$.

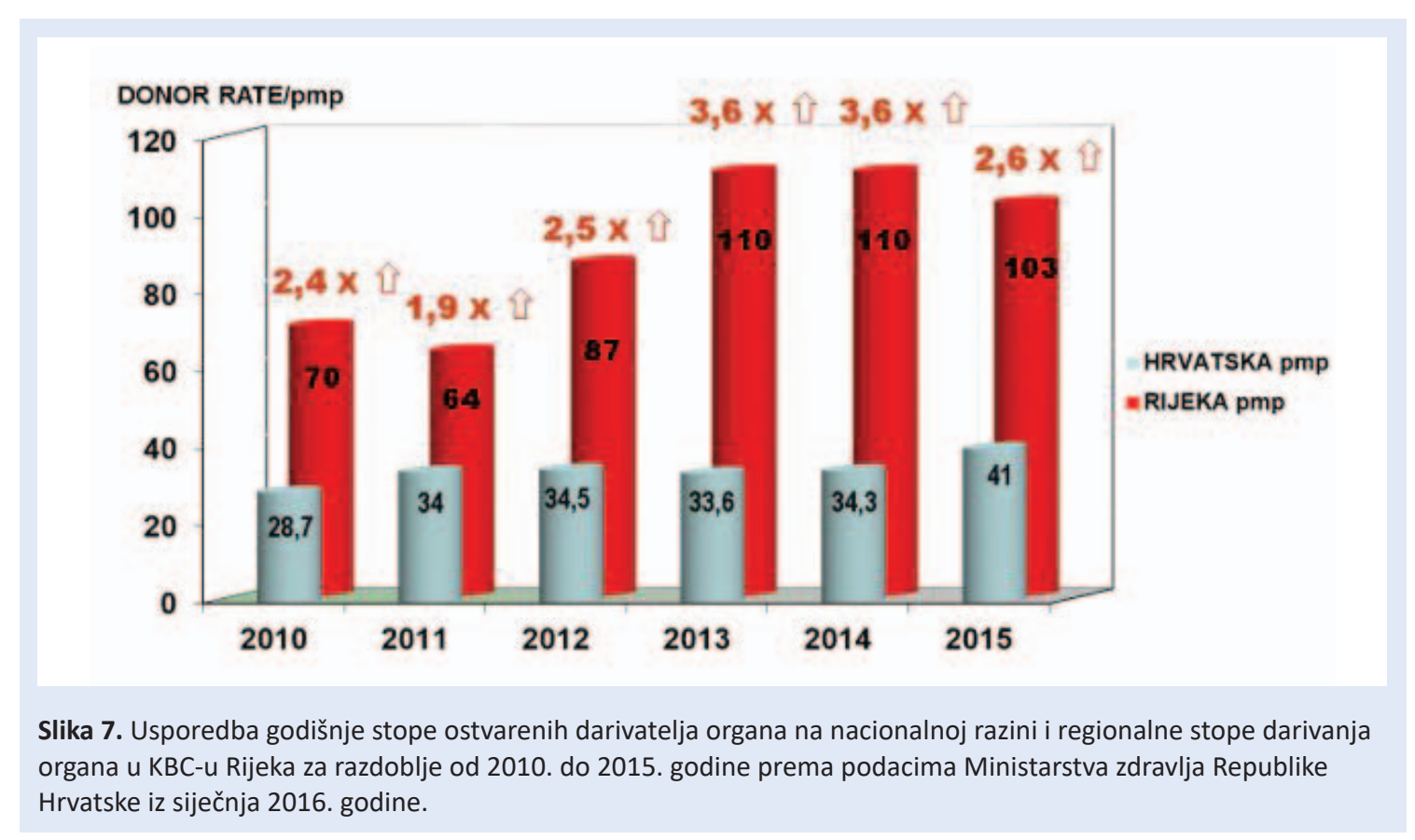


Regionalna stopa darivanja organa vrlo je varijabilna u Hrvatskoj, te unatoč odličnim rezultatima na nacionalnoj razini često značajno odstupa, nažalost, u negativnom smislu, od darivateljskih potencijala bolnica i regija.

Kao i u svijetu, i u Hrvatskoj je regionalna stopa darivanja dokazano ovisna o kompetencijama i uspješnosti BTK timova te prosječnoj stopi protivljenja unutar istih organizacijskih i financijskih okvira na nacionalnoj razini i istovjetne legislative ${ }^{27}$.

\section{BOLNIČKI TRANSPLANTACIJSKI KOORDINACIJSKI TIM}

BTK tim od 2006. godine čine glavni koordinator prof. dr. sc. Željko Župan, dr. med. anesteziolog, intenzivist te dvoje pomoćnika, prim. Branka Martinović-Sladoje, dr. med. nefrolog i Mladen Ivanovski, dr. med. anesteziolog, intenzivist. Sve članove tima imenuje $\mathrm{MZ}$, a broj pomoćnika određuje se temeljem rezultata bolničkog darivateljskog programa u prethodnoj godini. Do kraja 2014. navedeni bolnički koordinacijski tim obavljao je i niz dužnosti vezanih uz organizaciju kompletnog transplantacijskog programa KBC-a Rijeka. Ministarstvo zdravlja je recentno zadatke iz transplantacijske medicine preusmjerilo na članove novooformljenih bolničkih transplantacijskih centara, dok je darivateljski program u cijelosti ostao u domeni odgovornosti BTK tima.

BTK tim uz motivirane intenziviste ima ključnu ulogu u djelotvornosti bolničkih darivateljskih sustava i o njihovim kompetencijama, angažiranosti, posvećenosti i radnom kapacitetu u najvećoj mjeri ovisi djelotvornost bolničkog darivateljskog sustava. Član ili članovi BTK tima također moraju imati izražene liderske kapacitete sa stručnim autoritetom i komunikacijskim vještinama te neophodnom empatijom. S obzirom na navedene ostvarene rezultate i iznimnu djelotvornost sustava darivanja organa od umrlih unutar KBC-a Rijeka, evidentno je kako spomenuti bolnički BTK tim, sada već više od jednog desetljeća, vrlo uspješno vodi ovaj sustav.

\section{ZAKLJUČAK}

Hrvatska je jedna od vodećih zemalja svijeta po broju ostvarenih umrlih darivatelja organa i broju izvedenih transplantacija po glavi stanovnika go- dišnje. Na taj način velikom broju naših pacijenata $s$ terminalnim zatajivanjem pojedinih organa osigurana je visoka dostupnost transplantacijskom liječenju, jedinom uspješnom načinu njihova trajnog zbrinjavanja. KBC Rijeka je cijelo posljednje desetljeće zdravstvena ustanova $u$ državi s najuspješnijim bolničkim programom darivanja organa od umrlih te najboljim ostvarenim rezultatima u ovom vrlo osjetljivom području kliničke medicine.

Zahvaljujući navedenim dosezima u darivanju organa od umrlih, KBC Rijeka snažno se pozicionirao u vodeću zdravstvenu ustanovu na nacionalnoj razini, visokorespektabilnu i unutar međunarodne transplantacijske zajednice.

Izjava o sukobu interesa: Autor izjavljuje da ne postoji sukob interesa.

\section{LITERATURA}

1. Global Observatory on Donation and Transplantation [Internet]. Organ donation and transplantation activities. [cited 2019 December 16]. Available from: https:// www.transplant-opservatory.org.

2. Husen $\mathrm{P}$, Hornung J, Benko T, Klein C, Willuweit K, Buechter $\mathrm{M}$ et al. Risc factors for high mortality on liver transplant waiting list in times of organ shortage: a single centar analysis. Ann Transplant 2019;24:242-51.

3. Report of the Madrid Consultation: Part 1: European and universal challenges in organ donation and transplantation, searching for global solutions. Transplantation 2011;91:S39-66.

4. Delmonico FL, Domínguez-Gil B, Matesanz R, Noel L. A call for government accountability to achieve national self-sufficiency in organ donation and transplantation. Lancet 2011;378:1414-8.

5. Girlanda R. Deceased organ donation for transplantation: Challenges and opportunities. World J Transplant 2016;6:451-9.

6. Živčić-Ćosić $S$, Bušić $M$, Župan Ž, Pelčić $G$, Anušić Juričić $M$, Jurčić $Z ̌$ et al. Development of the Croatian model of organ donation and transplantation. Croat Med J 2013; 54:65-70.

7. Ministarstvo zdravstva Republike Hrvatske [Internet]. Uprava za bolničku zdravstvenu zaštitu, transplantaciju i biomedicinu, Sektor za transplantaciju i biomedicinu: statistički podaci. [cited 2019 December 16]. Available from: http://www.zdravlje.hr/programi_i_projekti/ transplantacijski_program/statistika.

8. Župan Ž. Program darivanja organa u Hrvatskoj i KBC Rijeka. Zbornik radova: Transplantacija bubrega u Rijeci: Povijesni osvrt i sadašnje stanje. Rijeka: HAZU, 2016;91-101.

9. KBC Rijeka, Program darivanja organa, raspoloživo u arhivi glavnog bolničkog transplantacijskog koordinatora, posljednji pristup prosinac 2019. godine.

10. Patel MS, Mohebali J, Sally M, Groat T, Vagefi PA, Chang DC et al. Deceased organ donor management: does hospital volume matter? J Am Coll Surg 2017;224:294-300. 
11. Fučkar Ž. Povijest transplantacije bubrega na Sušaku. Medicina Fluminensis 2010;46:352-9.

12. A definition of irreversible coma. Report of the Ad Hoc Committee of the Harvard Medical School to examine the definition of brain death. JAMA 1968;205:337-40.

13. Orlić $P$, Zelić $M$, Uravić $M$. 25 godina transplantacije bubrega u KBC Rijeka. Drugi Hrvatski simpozij o supstitucijskom liječenju renalne insuficijencije i transplantacijske medicine. Rijeka:1996;18A.

14. Bušić M. Darivanje i presađivanje organa - „Hrvatski model“. Medix 2011;17(92/93):144-8.

15. Matesanz R, Dominques-Gil B. Strategies to optimize deceased organ donation. Transpl Review 2007;21:177-88.

16. Župan Ž. The proposed 2011-2016 national strategy for timely and optimal management of organ and tissue donors. Medix 2011;17:149-55.

17. Arshad A, Anderson B, Sharif A. Comparison of organ donation and transplantation rates between opt-out and opt-in systems. Kidney Int 2019;95:1453-60.

18. Meyfriodt G, Gunst J, Martin-Loeches I, Smith M, Robba C, Taccone FS et al. Management of the brain death donor in ICU: general and specific therapy to improve transplantable organ quality. Intensive Care Med 2019;45:343-52.

19. Patel MS, Zatarain J, De La Cruz S, Sally MB, Ewing T, Crutchfield $\mathrm{M}$ et al. The impact of meeting donor management goals on the number of organs transplanted per expanded criteria donor: a prospective study from the UNOS Region 5 Donor Management Goals Workgroup. JAMA Surg 2014;149:969-75.

20. Salim A, Velmahos GC, Brown HC, Belzberg H, Demetriades D. Aggressive organ donor management signifi- cantnly increases the number of organs available for transplantation. J Trauma 2005;58:991-4.

21. Malinoski DJ, Patel MS, Daly MC, Oley-Graybill C, Salim A. The impact of meeting donor management goals on the number of organs transplanted per donor: results from the United Network for Organ Sharing Region 5 prospective donor management goals study. Crit Care Med 2012;40:2773-80.

22. Malinoski DJ, Patel MS, Daly MC, Oley-Graybill C, Foster CE 3rd, Salim A. Achieving donor management goals before deceased donor procurement is associated with more organs transplanted per donor. J Trauma 2011;71: 990-5.

23. Rosenblum AM, Li AH, Roels L, Stewart B, Prakash V, Beitel $J$ et al. Worldwide variability in deceased organ donation registries. Transpl Int 2012;25:801-11.

24. Ghorani F, Khoddami-Visheth B, Ghobadi O, Shafaghi S, Louyeh AR, Najafizadeh $\mathrm{K}$ et al. Causes of family refusal for organ donation. Transplant Proc 2011;43:405-6.

25. Shepherd L, O'Carroll RE, Ferguson E. An international comparison of deceased and living organ donation/ transplant rates in opt-in and opt-out systems: a panel study. BMC Medicine 2014;12:131-4.

26. Ministarstvo zdravstva Španjolske [Internet]. Izvješće Nacionalne organizacije za transplantaciju Španjolske o rezultatima u 2018. godini. [cited 2019 December 16]. Available from: www.lamoncloa.gob.es/lang/en/gobierno/news/Paginas/2019/190121transplant.aspx.

27. Tullius SG, Rabb H. Improving the supply and quality of deceased - organs for transplantation. N Engl J Med 2018;378:1920-9. 